\title{
Three Ways to be Craig Heron ${ }^{1}$
}

\author{
Steve Penfold, University of Toronto
}

In late May 2017, scholars from across Canada assembled to present research and reflections inspired by the work and career of Craig Heron, who would retire from York University that June. The conference organizers (Kate McPherson, Molly Ladd-Taylor, and myself) decided early on that we did not want a funeral, where Craig's friends would stand around saying nice things and eating little sandwiches. Better to aim for something intellectually useful, and we soon settled on the notvery-novel idea of research presentations that grew from the ideas and activities that animated Craig's career. This seemed like a fine plan at the time, but it soon became apparent that there were too many ideas and activities. Craig came to York in 1982, having already lived a pretty full life: a childhood in working-class Scarborough (a suburb of Toronto), New Left student activism, MAs from Toronto and Warwick, a Dalhousie PhD, and a handful of publications. ${ }^{2}$ He spent the next 35 years doing so many things that it was difficult to imagine covering it all. So instead of mounting a month-long conference, we narrowed our plan to a few basic themes: scholarship, activism, and public history. After a Call for Papers, these themes turned into seven sessions over a day and a half, including research and reflective papers on a wide range of topics. ${ }^{3}$ As one of the organizers of the conference (not to mention as one of Craig's former students), I am hardly in a position to comment on its success or limitations. It did, to be sure, demonstrate the breadth, range, and depth of Craig Heron's work and career. But now, with the task of reflecting on both Craig's career and the conference, I confront the same problem that we faced at the start: too many things to say, too many issues to cover, and too much activity to consider. How to say something coherent about a conference and a career of such impressive breadth? Every attempt seems to burst past its boundaries, so I will have to be strategic and reductionist, distilling it all down to Three Ways to Be Craig Heron.

\section{How to Be Craig Heron \#1: Get Busy}

Craig's CV might be longer than my last book - it is really big, reflecting a career spent researching, writing, editing, reviewing, talking, teaching, presenting, collaborating, commenting, meeting, marching, intervening, and administering. Just his publication record is impressive enough: nine books and edited collections, dozens of articles and chapters, countless reviews, and active and ongoing participation in Canadian and international conferences. Each of these efforts was deeply researched and based on an impressive mastery of key scholarly literatures. Craig's 
bibliographies often seem longer than the books themselves, and even his "think pieces" are rigorously footnoted. Take his 2000 article on public history, which purports to be "personal reflections on collaborative work," yet still manages 70 footnotes, which often take up more of the page than the text. ${ }^{4}$ Even more impressive is his ability to synthesize this research into clear and coherent arguments. While some of his books stretched to rather imperial lengths, ${ }^{5}$ others were remarkably tight, building succinct narratives on a stunning base of secondary and primary sources. Think Working in Steel, a crisp and concise distillation of several themes, locations, and developments. Or, consider The Canadian Labour Movement: A Short History, which admirably lives up to its subtitle in surveying a century and a half of workers' organizing. ${ }^{6}$ The same virtues can be found in his chapter-length synthesis of Canada's second industrial revolution and his underappreciated "Afterword" on workers and the Canadian state. ${ }^{7}$

Heron was not one of those prolific writers whose productivity came by withdrawing from the rest of academic and political life, finding an office in a faraway part of campus and hiding behind the word processor. Throughout his career, he remained an engaged teacher, an energetic activist, and a committed public historian. This point came out clearly at the conference, where several papers explored university politics and public history. Craig took his role as colleague and university citizen seriously. He did a term as Chair of York's unwieldy Division of Social Science, sat through endless Senate meetings, served on the executive of the York University Faculty Association (YUFA), walked that Association's picket line, and supported strikes by staff, sessionals, and teaching assistants. In all these capacities, he was absolutely dependable, always able to churn out a cogent and thoughtful discussion paper or open letter in reliable time. If that were not enough, Craig taught uncountable undergraduates in York's Division of Social Science and Department of History, and even took on the introductory Canadian survey in his senior years. As a graduate teacher, he supervised diverse topics (from snack food to summer camps, with labour, sexuality, and post-colonial studies thrown in) and sat on dozens of dissertation committees (I recall one sabbatical year where he read around 60 chapters).

Craig also took his role beyond York seriously. He did a three-year stint as the Vice Chair of the Ontario Heritage Foundation, helped to develop curriculum for the Toronto Board of Education, gave guest lectures to schoolteachers, made up a board game on family economy, and did multiple interviews for newspaper, radio, and television. I suspect he is most proud of co-founding the Workers' Arts and Heritage Centre in Hamilton, which required interminable meetings, fund raising, and perilous rush hour drives along Ontario's famously congested Queen Elizabeth Way. Even after retirement, he remains committed to broad audiences, helping to organize the Toronto Workers History Project. ${ }^{8}$ Craig's own talk at the conference, "The Public Intellectual," (which is included in this volume) explored these activities as a way to reflect on the broader trajectory of history in Canada. 


\section{How to Be Craig Heron \#2: Keep Reading}

Craig came of age academically as part of the wave of social history in the 1970s and 1980s. His central concern was obviously class, which was rooted personally in his own working-class background, politically in the New Left politics of his early adulthood, and intellectually in his exposure to British Marxism and the new American labour history. ${ }^{9}$ In many ways, his early work on strikes (written with Bryan Palmer), steel plants, and workers in mass production all reflect those intellectual priorities, although (to use Thompsonian terms) we find more time discipline than plebeian culture in these studies. ${ }^{10}$ "This essay will concentrate simply on the workplace crisis facing these craftsmen, without further reference to its implications for working-class ideology, politics, and social life," he announced at the beginning of "The Crisis of the Craftsmen," hardly a sentiment calculated to inspire flights of culturalism or to send us searching for an old photocopy of "Joe Beef."11 This onthe-job focus deepened in the 1980s as Craig helped revise Harry Braverman's depressingly one-dimensional model of de-skilling. ${ }^{12}$ But even if he focused mostly on work, the centrality of class experience, particularly through the window of conflict, remained clear.

Yet from the beginning, Craig adopted a broad notion of class. His PhD dissertation had a chapter on the emerging topic of women workers and, over time, he integrated many other conceptual frames: family, gender, childhood, sexuality, spectacle, reform, leisure, religion, and so on. In the 1990s, he published on family economy and schooling, and immersed himself in growing literatures on masculinity and on commemoration and parades. ${ }^{13}$ This breadth of vision culminated in Lunch Bucket Lives, a history of working-class Hamilton that began as his 1981 thesis but morphed into something much more by the time it was published in $2015 .{ }^{14}$ If we can still spot traces of the classic architecture of the local study-work, family, and community - the book nonetheless covers stunning ground, running from capitalists to workers, factories to kitchens, boardrooms to grocery stores, assembly lines to minstrel shows. Lunch Bucket Lives layers scholarly trend on scholarly trend, as much an encyclopedia of Canadian, British, and American historiography as a deeply empirical study of one industrial city. It is, to use Andrew Parnaby's words, "an inclusive, total history" in the best sense, "one of the few publications that have realized the promise of the discipline as a whole."15

Indeed, reviewing his key works, it is hard to pigeonhole Heron as a straight-up social historian. How do we read, for example, his brilliant article on Labourism except as Canadian political history? ${ }^{16}$ Both adjectives matter: it is Canadian, ranging from east to west, all while taking seriously local context and regional difference; it is political, focused on ideas and symbols but also mobilization and elections. The article is a reconstruction of an amorphous concept, but also a history of the institutions that tried to put Labourism into practice, with some electoral success in the years just after the First World War. ${ }^{17}$ Or take Booze: A Distilled History. 
It would be hard not to consider politics in a book about alcohol in a country that had large temperance movements, legal prohibition, and then highly-regulated regimes of drinking. But note Heron's rich handling of these politics, which draws keywords from the familiar dictionary of the social historian (the state, social movements, regulation, surveillance), but also deploys classic concepts like partisanship, patronage, and party. For example, his discussion of the dismantling of provincial prohibition regimes is filled with words like voters, lobbying, and elections. ${ }^{18}$ Similarly, if you go into Lunch Bucket Lives thinking of Heron as a stereotypical 1980s social historian, you will be surprised by the book's rich chapters on party politics, both working-class Toryism and its Lib-Lab rival. You will be even more surprised to find early versions of those chapters in his 1981 thesis. In this sense, much of Craig's work fits rather uncomfortably into the long and generally tedious debate between political and social history that raged amongst Canadian historians across his career. ${ }^{19}$

The impressive breadth of Craig's work partly flowed from his openminded approach to new scholarship. Take his handling of class experience. Early working-class history was sometimes criticized as romantic. ${ }^{20}$ The charge seemed unfair, but it is certainly true that attention gravitated to resistance more than accommodation, to strikers more than scabs, to drinkers more than teetotalers, to the activist more than the apathetic, and to class conflict more than labour peace. The longest chapter of Working in Steel, for example, is on Resistance-a priority that proves useful and illuminating as well as thoroughly understandable within the structure/agency frame of that first creative burst of working class history. But compare it to "Harold, Marg, and the Boys," Heron's autobiographical Presidential Address to the 2009 meeting of the Canadian Historical Association (CHA). Heron charts historiographical change in terms of his own family experience: through stories of his electrician father (Harold), the domestic and paid work of his mother (Marg), and the different career trajectories of he and his brother (the boys). The result is a nuanced reflection both on historiography and on one thread of postwar working class experience. Certainly, in early working class history, with its emphasis on conflict, we would strain hard to find sentences like, "[Harold] had no enthusiasm for the union, rarely went to its meetings or read its monthly magazine, stayed home during its only strikes, and expressed no affinities with the broader labour movement." ${ }^{21}$ Harold and Marg did much to make their own lives (in circumstances, as we say, not entirely of their choosing), but the word "resistance" hardly appears in the article at all. Instead, Craig finds "working class realism," a subtle and illuminating concept that sometimes points toward mobilization, other times toward retreat, and always to daily struggles with money, authority, independence, and respectability. Yet in Heron's hands, working class realism remains rooted in the broad context of the postwar period: the Heron family was crucially shaped by economic boom, union organization, and the state programs that flowed from the socalled postwar compromise. For Heron, all this helps us understand the complexities 
of class experience, a concept and phrase that appears several times in the article. ${ }^{22}$ "Harold, Marg, and the Boys" also returns to the central subject of Heron's scholarship: the white, urban, industrial working class, mostly in southern Ontario. Booze is a partial exception, with its national scale and wide-ranging discussions of advertising, temperance, and other themes, but even there, workingclass engagements with alcohol remain analytically central. ${ }^{23}$ This cross-career focus allowed Craig to integrate new literature by applying it to a consistent subject and to a core set of analytic questions - an approach perfectly summed up by the singular topical focus and impressive analytic expansiveness of Lunch Bucket Lives. Still, even as an admirably total history, Lunch Bucket Lives is not totally total. While we would have to search the book hard for outright historiographical silences, it seems less completely engaged with race than other themes. Lunch Bucket Lives does contain several references to whiteness, an illuminating chapter on Britishness and imperialism amongst Hamilton workers, and some interesting material on race in popular culture and on the Hamilton African-Canadian community. Overall, however, race seems less developed and less woven into the various chapters than the expansive exploration of work, gender, family, and community. Similarly, the articles that led up to the book show Craig's serious engagement with feminist scholarship and gender history (bringing household, masculinity, femininity, and domesticity to bear, in substantive ways, on his consideration of working class experience). But unlike gender, race (while present) was most often a modifier in Craig's work and never became the central subject to be examined, a point made clear in titles like "Boys will be Boys" and "The Boys and their Booze." 24 In this sense, his core subject remained the mostly white, central Canadian, urban, industrial working class, with all its richness and limits.

Moreover, throughout his expansive reading and intellectual evolution, Heron mostly remained a Canadian historian. He read widely in American, British, and international historiography, made occasional comparisons to other places, and undoubtedly contributed to an international understanding of capitalism and class. ${ }^{25}$ Yet he seems less taken by the so-called transnational turn than some of his juniors, an intellectual impulse reinforced by his key audiences and his intellectual networks. He frequently attended the North American Labour History Conference at Wayne State University, but presented to the CHA much more religiously, culminating in his role as president from 2007-2009. The nation was also reflected in the structure of the York conference. It was hardly a local affair (presenters came from Victoria, Edmonton, Winnipeg, Fredericton, and many other places), but it made few connections beyond Canada (its one presenter from across the $49^{\text {th }}$ parallel was Jason Russell from Empire State College in western New York, who is Canadian and a York alumnus). Papers were topically diverse (class, sexuality, religion, popular culture, public history, university governance) but almost universally Canadian in scope. When matters during a Q\&A turned to considering some fundamental questions of Canadian capitalism, the discussion mostly charted categories from left nation- 
alist debates of the 1970s (dependence, the Waffle, Innis and Marx, etc). It was an interesting moment, to be sure, but had less to say about Canadian capitalism's international role as an agent of the country's own imperial past, or about more recent work on infrastructural and resource colonialism within national borders. ${ }^{26}$

In this sense, while Heron was a key part of a generation that expanded Canadian history profoundly, he (and they) mostly shared with traditional political history "the presumption that the nation was the appropriate container of historical knowledge and inquiry." 27 In the introduction to Lunch Bucket Lives, Hamilton is briefly placed in various geographic scales (southern Ontario, Canada, and the urban-industrial Great Lakes), but these references mostly serve to set the scene rather than shape the story. Geography does not press in much on the subsequent analysis, and there is little ongoing reflection on where and how Hamilton should be placed. Of course, Lunch Bucket Lives is a local study, but the nation set borders across Heron's career. In the edited volume, The Workers' Revolt in Canada, Heron and a number of scholars published illuminating essays on a key moment in class struggle. Yet the frame is unquestionably Canadian. The Introduction begins with international context ("In 1919 the clenched fist of working-class solidarity was raised defiantly throughout the industrialized world," with references to Russia, France, Scotland, and other places) but attention quickly returns to Canada ("What was happening in Canada?" the introduction asks four paragraphs in, shifting ground to a discussion of regional differences). The last chapter and conclusion speak, explicitly in the former case, to the national rather than international contours of the revolt. In general, the key historiographical target of Workers' Revolt is an earlier debate between Canadian historians about the national or regional nature of workers militancy. ${ }^{28}$

When historians of Heron's generation deconstructed the national, in other words, the direction was typically toward the smaller (to region or community) rather than the larger (to global and transnational). ${ }^{29} \mathrm{I}$ have never asked him directly about the source of this geographic focus and national frame. Perhaps it is a mix of assumption and decision, a combination of hard-wired training in national history, tacit knowledge reinforced by Canadian intellectual networks, and explicit (though often critical) engagement with the left nationalism of the 1970 s. If pressed, however, he would probably churn out a thoughtful reflection for Left History, no doubt featuring 287 footnotes, on the continued relevance of the nation and Canadian history.

\section{How to Be Craig Heron \#3: Practice Critical Generosity}

Craig's long career might be best summed up with the phrase "critical generosity." On the one hand, he had clear ideas about how to do history. He was an earnest scholar and often tough-minded. As a supervisor, he was no easy critic-anyone who wound up on the wrong end of his editorial pen probably felt the need for a 
support group. Still, he remained generous and supportive and his interventionsat least in my experience-always aimed to make the work stronger rather than to force his own agenda. He approached his own scholarship in a similar way. His generation of historians sometimes mixed intellectual debate with what seemed (to some of their grad students) like baffling and unnecessary personal disputes. Looking back, perhaps it is best to read those dynamics generously: he was part of a thoughtful and earnest cohort of historians who took scholarship seriously as a political act. Still, in his later work, I rarely sensed the crankiness that can develop in the senior and experienced. His think pieces tended to be rhetorically gentle, historiographically inclusive, and deeply empirical. "Harold, Marg, and the Boys" is a call to action of sorts, but it is broad, open, and rooted in evidence. Its concluding plea for the continued relevance of class is delivered as an invitation, not a refusal. Craig laments that class "has slipped out of common usage in the writing of a good deal of history in recent years," yet he wants us all "to incorporate the many complexities and complications that all the rethinking of class has brought about." ${ }^{30}$ As a prescription, it features more footnotes than fury. Perhaps as a result of this generous approach, the York conference spanned academic generations, from some pioneers of labour and social history in Canada (Greg Kealey, Ian McKay, David Frank, and others) to mid-career folks (Lynne Marks, Adele Perry, and others) and emerging scholars (Tom Hooper, Peter Stevens).

Craig's talk at the conference made a strong case for activist and publiclyengaged history, and wrapped things up on an inclusive and positive note. He put his public history work in a broad collective context, pointing to many efforts by historians to reach big audiences. Indeed, the retreat from the public has always been exaggerated. Despite repeated laments in various journals about the ivory tower historian, many scholars have been and continue to be deeply committed to reaching wider audiences, even if their books do not appear in airports alongside biographies of Winston Churchill and Adolf Hitler. Craig made this point often in his career. "Historians of the working class in Canada have seldom been comfortable in an ivory tower," he wrote almost two decades ago. "Lurking within even the most dedicated scholars in the field is the popular educator who wants to participate in a wider dissemination of knowledge." ${ }^{31}$ There are, after all, many ways to reach out, and many audiences to reach. At the conference, generous as always, Craig explicitly pointed to recent efforts of young scholars to reach out through podcasts, popular writing, and public talks. He finished with a plug for Active History, a website that publishes short and accessible articles on historical topics and reaches many more readers than the typical academic journal. ${ }^{32}$ 


\section{A Conclusion: Craigitivity Revealed!}

As I look back on the work and career of Craig Heron, and on the York conference, I think not of total histories and intellectual evolution but of a blurry photo of a demonstration from the mid-1990s, now stuffed in a box at the back of my basement. It was taken at one of the many marches against the right-wing agenda of Premier Mike Harris. I think it was in London, Ontario, or perhaps Hamilton. Everyone looks damn cold: toques, scarves, hoods, and balaclavas are in great abundance, to the point that you can hardly see faces. In the distance, however, you can clearly spot Craig Heron's head poking above the throng. I cannot remember what he is doing - perhaps chanting loudly, bantering with his fellow marchers, or snapping a photo. It is a common memory. Craig is very tall, and at a demonstration it often seemed that you could see from him everywhere. "If you get lost," we used to say as the mob started to jostle, "meet at Craig." As it works literally for demonstrations, so it does metaphorically for history. It is good to know a friendly person who stands above the crowd.

\section{NOTES}

${ }^{1}$ For comments on a pretty terrible earlier draft, thanks to Sean Mills, James Muir, and Adele Perry.

2 Craig Heron, "Working-Class Hamilton, 1895-1930" (PhD diss., Dalhousie University, 1981); Craig Heron, ed., Imperialism, Nationalism, and Canada: Essays from the Marxist Institute of Toronto (Toronto: Between the Lines, 1977); Craig Heron and Bryan Palmer, "Through the Prism of the Strike: Industrial Conflict in Southern Ontario, 1901-14," Canadian Historical Review 58, no. 4 (December 1977): 423-458; Craig Heron, "Punching the Clock," Canadian Dimension 14, no. 3 (April 1979): 26-29; Craig Heron, "The Crisis of the Craftsman: Hamilton's Metal Workers in the Early Twentieth Century," Labour/Le Travail 6 (Autumn 1980): 7-48; Craig Heron, Shea Hoffmitz, Wayne Roberts, and Robert Storey, All That Our Hands Have Done: A Pictorial History of Hamilton Workers (Oakville: Mosaic Press, 1981); Craig Heron, "Hamilton Steelworkers and the Rise of Mass Production," Historical Papers 17, no. 1 (1982): 103-131.

${ }^{3}$ The program is available here: http://history.laps.yorku.ca/scholarship-activismpublic-history-a-celebration-of-the-work-and-leadership-of-craig-heron/.

${ }^{4}$ Craig Heron, "The Labour Historian and Public History," Labour/Le Travail, 45 (Spring 2000), 171-197. 
${ }^{5}$ Craig Heron, Booze: A Distilled History (Toronto: Between the Lines, 2003) comes in at 497 pages and Lunch Bucket Lives: Remaking the Workers City (Toronto: Between the Lines, 2015), 761.

${ }^{6}$ Craig Heron, Working in Steel: the early years in Canada, 1883-1935 (Toronto: McClelland \& Stewart, 1988); Craig Heron, The Canadian Labour Movement: A Short History (Toronto: J. Lorimer, 1989), and then new editions in 1996 and 2012.

${ }^{7}$ Craig Heron, "The Second Industrial Revolution in Canada, 1890-1930," in Class, Community and the Labour Movement: Wales and Canada, 1850-1930, eds. Deian R. Hopkin and Gregory S. Kealey (Society for Welsh Labour History and the Canadian Committee on Labour History, 1989), 48-66; Craig Heron, "Male Wage Earners and the State in Canada," in Workers and the State in Twentieth Century Nova Scotia, ed. Michael Earle (Fredericton: Acadiensis Press, 1989), 241-264.

${ }^{8}$ See http://twhp.ca.

${ }^{9}$ For an early discussion of the different influences and threads of class history in Canada, see Ian McKay, "The Three Faces of Canadian Labour History," History Workshop 24 (1987): 172-178.

10 "Through the Prism of the Strike"; "Hamilton Steelworkers."

11 "The Crisis of the Craftsman," 8; Peter DeLottinville, "Joe Beef of Montreal: Working-Class Culture and the Tavern, 1869-1889," Labour/Le Travail 8/9 (Autumn 1981/Spring 1982): 9-40. Heron's early work seems in line with the way many American historians were studying the workplace. See David Montgomery, Workers' Control in America: Studies in the History of Work, Technology, and Labor Struggles (New York: Cambridge University Press, 1979). In Canada, pioneering texts include Gregory Kealey, Toronto Workers Respond to Industrial Capitalism (Toronto: University of Toronto Press, 1980), and Bryan Palmer, A Culture in Conflict: Skilled Workers and Industrial Capitalism in Hamilton, Ontario, 1860-1914 (MontrealKingston: McGill-Queen's University Press, 1979).

${ }^{12}$ The main text here is Craig Heron and Robert Storey, eds., On the Job: Confronting the Labour Process in Canada (Montreal and Kingston: McGill-Queen's University Press, 1986). The key Braverman text is Labor and Monopoly Capital: The Degradation of Work in the Twentieth Century (New York: Monthly Press, 1974). ${ }^{13}$ At the York conference, Lynne Marks gave an interesting talk on Heron's nuanced engagement with questions of class and religion: Lynne Marks, "Craig Heron and the Social History of Religion in Canada.” For Heron's work on family, childhood, and education, see "The High School and the Household Economy in Working Class Hamilton," Historical Studies in Education 7, 2 (September 1995), 217-259. On masculinity: Craig Heron, "Boys will be Boys: Working Class Masculinities in the Age of Mass Production," International Labor and Working Class History 69 (Spring 2006), 6-34; Craig Heron, "The Boys and their Booze: Masculinities and Public Drinking in Working-Class Hamilton, 1890-1946," Cana- 
dian Historical Review 86, 3 (September 2005), 411-52. On parades: Craig Heron and Steve Penfold, “'The Craftsmen's Spectacle: Labour Day Parades in Canada, the Early Years," Histoire sociale/Social History 58 (November, 1996), 357-90. This latter article was mostly written by Craig, despite the co-authorship.

${ }^{14}$ Craig Heron, Lunch Bucket Lives: Remaking the Workers' City (Toronto: Between the Lines, 2015).

15 Andrew Parnaby, Review of Lunch Bucket Lives, Labour/Le Travail 78 (Fall 2016): 321. Gregory Kealey's blurb calls the book "an outstanding histoire totale."

${ }^{16}$ Craig Heron, "Labourism and the Canadian Working Class," Labour/Le Travail 13 (Spring 1984), 46-76.

${ }^{17}$ In this sense, "Labourism" also flows from the interest in labour politics shared by almost all the early proponents of new working class history in Canada. See Gergory Kealey, "Labour and Working-Class History in Canada: Prospects in the 1980s," Labour/Le Travail 7 (Spring 1981): 69.

${ }^{18}$ Heron, Booze, 269-296.

${ }^{19}$ For a sampling of key Canadian texts in this long debate, see Michael Bliss, "Privatizing the Mind: The Sundering of Canadian History, the Sundering of Canada," Journal of Canadian Studies 26, no. 4 (1992), 5-17, and responses in Journal of Canadian Studies 27, no. 2 (Summer 1992), 123-135; Jack Granatstein, Who Killed Canadian History? (Toronto: Harper-Collins, 1998); Brian McKillop, "Who Killed Canadian History? A View from the Trenches," Canadian Historical Review 80 (June, 1999): 269-299. Thankfully, this debate seems to have died of old age some time ago, although it still occasionally emerges from its grave to wander, zombie-like, through polemics in popular media.

${ }^{20}$ Terry Morley, "Canada and the Romantic Left," Queen's Quarterly 86, no. 1 (Spring, 1979): 110-119.

${ }^{21}$ Craig Heron, "Harold, Marg, and the Boys," Journal of the Canadian Historical Association 20, no. 1 (2009): 14.

${ }^{22}$ I counted three instances of "resistance" (two having to do with Harold's "boyish resistance to domestic burdens and tensions") and at least 15 references to "experience." See "Harold, Marg, and the Boys."

${ }^{23}$ Craig Heron and Steve Penfold, The Workers' Festival: A History of Labour Day in Canada (Toronto: University of Toronto Press, 2005) also aspires to a national scale.

${ }^{24}$ See "Boys will be Boys" and "The Boys and their Booze."

${ }^{25}$ For example, Heron's "Second Industrial Revolution" makes several comparisons to American developments. "Boys will be Boys" (published in an Americanbased journal) mostly frames Hamilton as an example of a North American industrial city rather than an explicitly Canadian one. 
${ }^{26}$ See, for example, Karen Dubinsky and Marc Epprecht, "Canadian Business and the Business of Development in the 'Third World'," in Canada and the Third World: Overlapping Histories, eds. Karen Dubinsky, Sean Mills, and Scott Rutherford (Toronto: University of Toronto Press, 2016), chapter 3; Adele Perry, Aquaduct: Colonialism, Resources, and the Histories We Remember (Winnipeg: ARP Books, 2016); Paul Sabin, "Voices from the Hydrocarbon Frontier: Canada's Mackenzie Valley Pipeline Inquiry (1974-1977)," Environmental History Review 19, no. 1 (1995): 1748; Caroline Desbiens, Power from the North: Territory, Identity, and the Culture of Hydroelectricity in Quebec (Vancouver: University of British Columbia Press, 2013); Hans Carlson, Home is a Hunter: The James Bay Cree and Their Land (University of British Columbia Press, 2008). Note the discussion in H.V. Nelles and Christopher Armstrong, Southern Exposure: Canadian Promoters in Latin America and the Caribbean, 1896-1930 (Toronto: University of Toronto Press, 1988), a fairly straight-up business history but far ahead of its time in geographic focus. ${ }^{27}$ Adele Perry, Karen Dubinsky and Henry Yu, "Introduction," in Within and Without the Nation: Canadian History as Transnational History, eds. Adele Perry, Karen Dubinsky and Henry Yu (Toronto: University of Toronto Press, 2015), 8. In his excellent piece on international and diplomatic history, David Meren makes a similar point from a different direction: "Although these new [social and cultural] histories left the national frame largely in tact, they did call into question the idea of the nation - and nation building - which was strongly associated with Canadian diplomatic history, notably its legalistic and political focus and its teleological logic. Instead, they posited identities and bases of community such as region, class, gender, and race as being equally, if not more, important subjects of study." David Meren, "The Tragedies of Canadian International History," Canadian Historical Review 96, no. 4 (December, 2015): 551. See also Franca Iacovetta, "Gendering Trans/National Historiographies: Feminists Re-Writing Canadian History," Journal of Women's History 19, no. 1 (Spring, 2007): 206-213.

${ }^{28}$ Craig Heron, ed., The Workers' Revolt in Canada, 1917-1925 (Toronto: University of Toronto Press, 1998). To be clear: the volume is concerned with many more issues than the question of region, but the collection clearly aims to understand the revolt as a Canadian phenomenon with regional variations. For the earlier debate, in which David Bercuson attributed union militancy in the regional factors and Gregory Kealey (based on a formidable reading list!) reconstructed the crosscountry dimensions of strikes and militancy, see Bercuson "Labour Radicalism and the Industrial Frontier," Canadian Historical Review 58, no. 2 (June, 1977): 154 177 and Kealey, “1919: The Canadian Labour Revolt," Labour/Le Travail 13 (Spring, 1984): 11-44. "The radical west and the conservative east," Kealey argues, "have become sorry Shibboleths of Canadian historiography," 15.

${ }^{29}$ For an alternate approach with some Canadian content - a trans-national collection for an international revolt, edited by Canadian scholars-see Karen Dub- 
sinky, Catherine Krull, Susan Lord, Sean Mills, and Scott Rutherford, eds., New World Coming: The Sixties and the Shaping of Global Consciousness (Toronto: Between the Lines, 2009).

30 "Harold, Marg, and the Boys," 2, 26.

${ }^{31}$ Heron, "The Labour Historian and Public History," 171.

${ }^{32}$ See http://activehistory.ca 